\title{
Superficial Intracranial Venous System
}

National Cancer Institute

\section{Source}

National Cancer Institute. Superficial Intracranial Venous System. NCI Thesaurus. Code C33662.

A group of blood vessels at the surface of the brain carrying deoxyg enated blood which include the superior, median, and inferior cerebral veins. 